University of Nebraska - Lincoln

DigitalCommons@University of Nebraska - Lincoln

Papers in Biotechnology

Chemical and Biomolecular Engineering

Research and Publications

January 1990

\title{
Enzyme- Facilitated Transport and Separation of Organic Acids through Liquid Membranes
}

\author{
David C. Rethwisch \\ Depaertment of Chemical and Biochemical Engineering and biocatalysis research Group, University of \\ lowa, lowa.
}

Anuradha Subramanian

Department of chemical Engineering,University of Nebraska Lincoln., asubramanian2@unl.edu

Gao Yi

Department of Chemical and biomolecular Engineering and Biocatalysis Research Group, University of lowa

Jonathan S. Dordick

Department of Chemical and biomolecular Engineering and Biocatalysis Research Group, University of lowa

Follow this and additional works at: https://digitalcommons.unl.edu/chemeng_biotechnology

Part of the Biochemical and Biomolecular Engineering Commons

Rethwisch, David C.; Subramanian, Anuradha; Yi, Gao; and Dordick, Jonathan S., "Enzyme- Facilitated Transport and Separation of Organic Acids through Liquid Membranes" (1990). Papers in Biotechnology. 32.

https://digitalcommons.unl.edu/chemeng_biotechnology/32

This Article is brought to you for free and open access by the Chemical and Biomolecular Engineering Research and Publications at DigitalCommons@University of Nebraska - Lincoln. It has been accepted for inclusion in Papers in Biotechnology by an authorized administrator of DigitalCommons@University of Nebraska - Lincoln. 


\section{Enzyme-Pacilita ted Transpart and Separator of Organic Acids through Liquid Membranes}

David C. Rethwisch, Anuradha Subramanian, Gao Yi and Jonathan S, Dordick

(C) American Chemical Society. Journal of American Chemical Society, 1990, 112 1649-1650

A

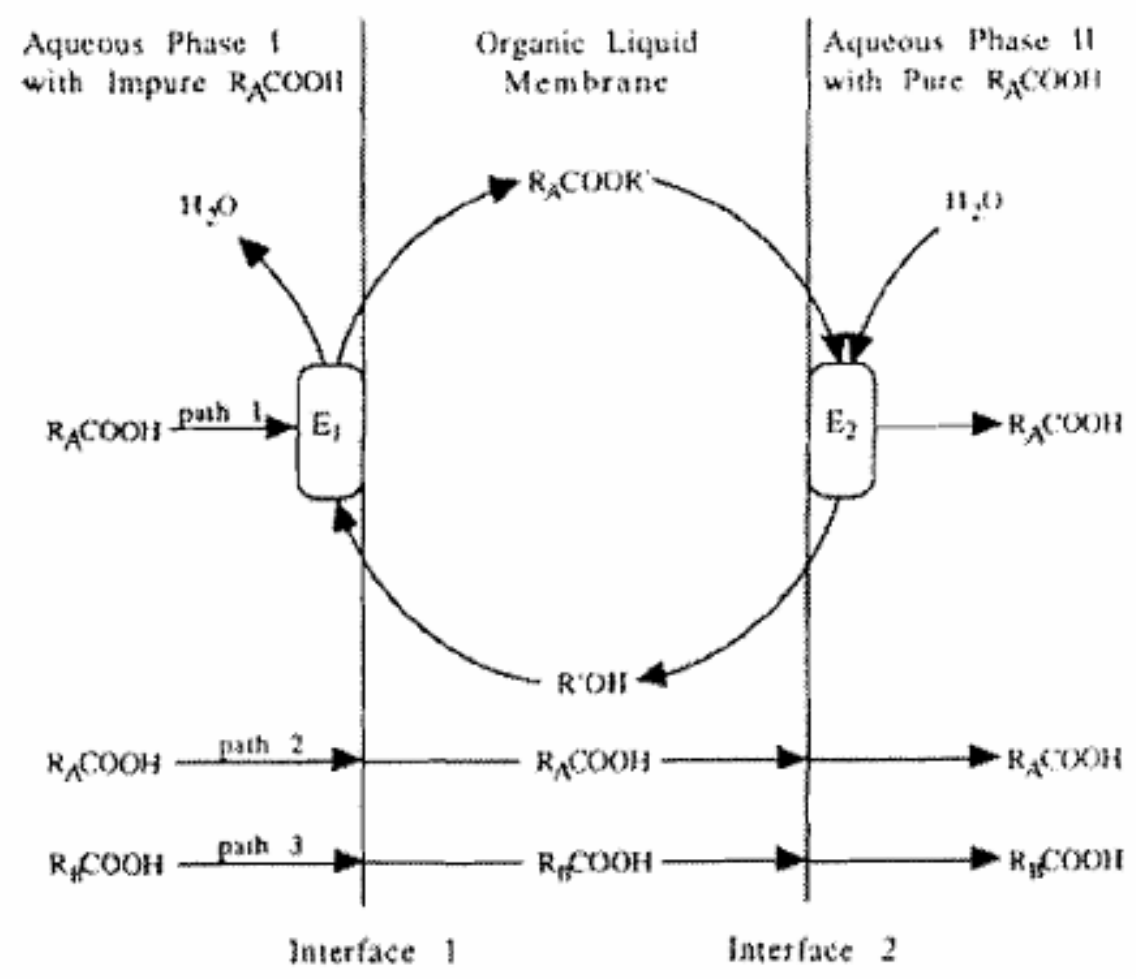

B

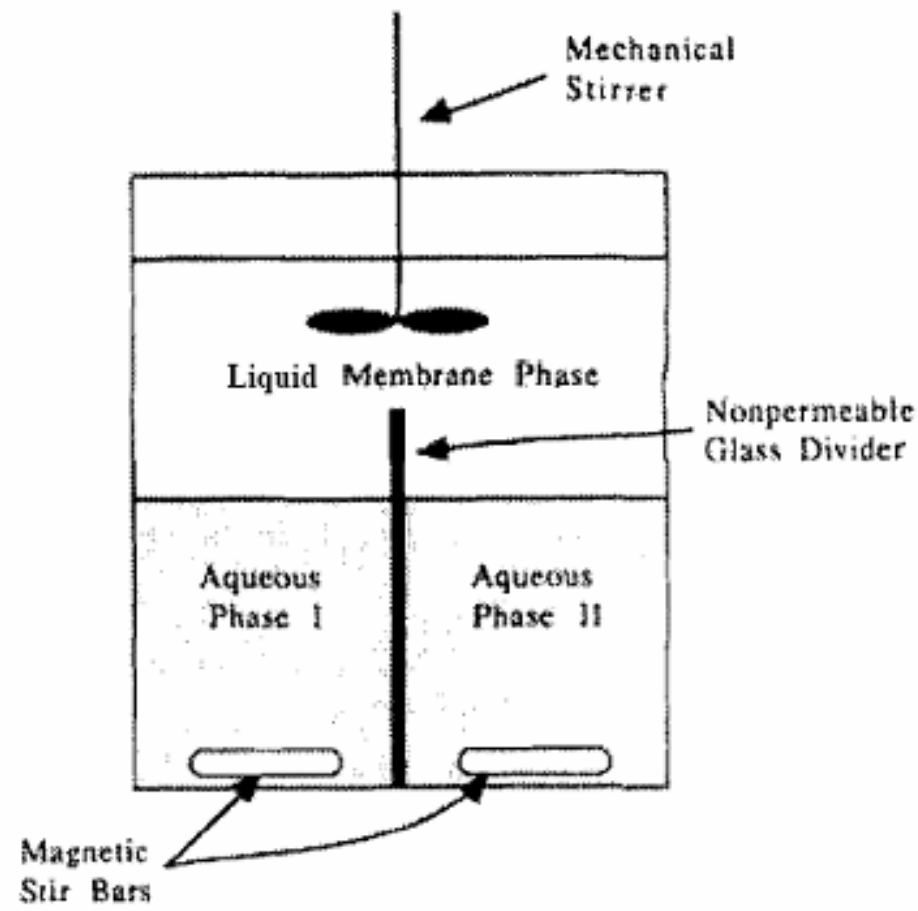

